\title{
A new approach to unilateral and bilateral lobotomies for psychomotor epilepsy
}

\author{
ERIC TURNER
}

From Queen Elizabeth Hospital, Birmingham

The surgical treatment of focal epilepsy cannot be regarded with satisfaction. Formerly (Foerster and Penfield, 1930) an area of scarring was excised but later with the aid of electrocorticography surgical excision was directed more to an area of abnormal electrical activity which might be near a scar or destructive lesion (Penfield and Paine, 1955).

Temporal lobe epilepsy received close attention and Penfield's observations on focal stimulation in the conscious patient were employed to aid in identifying epileptogenic zones (Penfield and Jasper, 1954). In time, larger volumes of tissue were removed in the first instance and partial temporal lobectomy has been much practised in recent years (Penfield and Flanigin, 1950; Bailey, Green, Amador, and Gibbs, 1953; Falconer, Hill, Meyer, Mitchell, and Pond, 1955). Even so difficulties have been encountered owing to the strong tendency for abnormal temporal lobe activity to be bilateral. The effects of bilateral temporal lobectomy on memory have been disastrous but they have contributed to our knowledge of the physiology of memorizing (Scoville and Milner, 1957; Russell and Espir, 1961).

Recent physiological advances demonstrate the extent to which different areas of the brain are in such close relationship to others that mutual interaction on thresholds of activity can be assumed and indicate a holistic view of brain function. To express this hypothesis in another way, the brain can be considered as a number of goal-seeking circuits with descending and ascending influences competing for the central neuronal pool. Some of these descending systems involve the temporal lobes which are very rich in connexions with other parts, including the diffuse projection systems of the thalamus, hypothalamus, and reticular formation.

It is reasonable therefore in the light of current knowledge to attempt the treatment of focal epilepsy not by excising brain but by exploring the effect of interrupting connexions to and from the part of the brain affected, theoretically leading to a useful degree of cure with a minimum of deficit.
METHODS AND MATERIAL

In cases of temporal lobe epilepsy the best site at which to cut fibre pathways involves some conjecture but as far as the present study is concerned the following procedures have been used: 1 Section of the tracts leading through the isthmus of the temporal lobe through which many important connexions pass to other parts of the brain; 2 section between the uncus and the main body of the hippocampus; 3 section of fibres in the basal frontal lobe region sweeping backwards and upwards from the orbital surface of the frontal lobe.

I am concerned principally with the results of the first procedure on the incidence of various types of epilepsy. Most of the patients in the series had abnormalities of temperament leading to disturbed social relationships: some were frankly psychotic, eight had a hemiparesis, and most had evidence of organic mental impairment on testing before operation.

Special investigations comprised scalp electroencephalography, the use of sphenoidal leads with the patient under pentothal, and ventriculography. Angiography was included if there was any indication for it. The patterns of electrodes with the sphenoidal leads included naso-pharyngeal and frontal, temporal, and parietal scalp contacts in order that abnormalities might be analysed in depth. The ventriculogram was performed by inserting $1.5 \mathrm{ml}$. Myodil through parietal burr holes into each ventricle. The patient's head was then flexed forwards when the Myodil flowed into the temporal horns. The rest of the ventricular system was outlined by replacement of cerebrospinal fluid with oxygen in the usual way just before the injection of Myodil. The ventriculogram was radiographed with the incident ray through bars in the external meati in the case of the laterals, and in the midline in Reid's plane for the posteroanterior view. By this means measurements were read and calculated for use in a modified Sherwood stereotaxic frame.

Three types of operation were employed, the first during the whole period reviewed and two in later periods in the light of greater experience. This paper can be taken as an intermediate report on the first and a preliminary report on the other two.

OPERATION 1 This consisted of a quadrantic cut in the coronal plane, through the roof of the temporal horn 
$1 \mathrm{~cm}$. posterior to the tip, but subject to the modification that in very long temporal horns it was not more than $1.5 \mathrm{~cm}$. anterior to the intermeatal line $(A+1.5)$ and that in very short temporal horns it was not behind the intermeatal line $(A=0)$. The radius of the cutting blade of the leucotome (Fig. 3) was $1 \mathrm{~cm}$. After the stereotaxic frame had been applied the tip of the instrument was inserted horizontally through a burr hole in the temporal bone to the point at the upper edge of the ventricle, not beyond the most lateral portion of its medial edge in the postero-anterior projection. This meant that the lateral coordinate was that of the point where the impression of the uncus joined the medial line of the main descending horn. The optic tract was not in danger provided the instrument did not pass medial to this point. When the leucotome was inserted the blade was rotated upwards a little just before it was pushed fully home. The choroid plexus thus did not become caught in the blade which was swept up and down several times, and pulled slightly in the open position to ensure that the fibres were properly cut. During the first centimetre of withdrawal the blade was left slightly open (about $20^{\circ}$ ) again to avoid nipping the choroid plexus. The cut is outlined in the section in Figure 1. (The leucotome was a modification of the Warlingham Park instrument (McGregor and Crumbie, 1941) and was made by Down Brothers.) The blade was single ended, and the shank was $10 \mathrm{~cm}$. long, being made specially to reach the appropriate distance from the carrier'. At first local anaesthesia was used to allow of constant checking of the visual fields but later general anaesthesia was employed.

OPERATION 2 The second operation consisted of a similar coronal cut downwards through the hippocampus, making a section through the alveus and the underlying formation between the uncus rostrally and the main body of the hippocampus caudally. The section consisted of the lower half of the circle of which the first operation represented rather more than the upper and medial quadrant.

OPERATION 3 The third operation was a basal frontal lobotomy designed to cut fibres sweeping backwards and upwards from the orbital surface of the frontal lobe (Reitman, 1946; Dax and Radley-Smith, 1948; Dax, Freudenberg, Reitman, and Radley-Smith, 1948). Frontal burr holes were made $3 \mathrm{~cm}$. behind the lateral orbital margin and $6 \mathrm{~cm}$. above the superior border of the zygomatic arch in a plane passing through a point $10 \mathrm{~cm}$. behind the nasion measured along the scalp in the sagittal line. A basal cut was made in a plane passing through a point $13 \mathrm{~cm}$. behind the nasion measured along the scalp in the sagittal line, with its upper edge in the line directed at a point $1 \mathrm{~cm}$. below the lower edge of the opposite burr hole.

CHOICE OF OPERATION The first operation was performed in all cases and is our chief concern. The main criteria of selection for operative treatment were focal discharges at one or both temporal bases independently, together

${ }^{1}$ Another instrument for stereotaxy is now in use, demanding a longer shank. with a clinical history of major psychomotor attacks intractable to thorough medical treatment. The reason for the choice of operation depended on the fact that a majority of the patients had temperamental disturbances, usually in the form of bouts of uncontrollable rage, aggression, and often violence. Bilateral temporal lobectomy in Rhesus monkeys led to tameness, among other symptoms described by Klüver and Bucy (1939). Study of the physiological evidence and the results of small lesions in the temporal isthmus led to the conclusion (Turner, 1954, 1955) that descending influences conveying reactions of fear and aggression passed through the isthmus, whereas the hippocampus was concerned with memorizing of recently acquired information and with voluntary recall of memories.

The operation was therefore directed to benefit not only the fits but also the mental state of the patient. Thus additional operations might be performed if the mental state or minor attacks of epilepsy remained unsatisfactory after the first operation.

\section{RESULTS}

Operation no. 1 was carried out alone in 20 cases (Table I) and the improvement in the frequency of fits both major and minor was often most gratifying

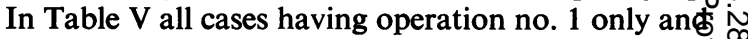
followed up for over two years are entered. I addition in the lower part of the table are entere $\Phi^{\circ}$ patients who had operation no. 1 and were followe f $^{-}$ up for over two years before further operations were embarked upon. The effect on the epilepsy during these two years is clearly indicated.

\section{TABLE I}

NUMBERS OF DIFFERENT TYPES OF OPERATION PERFORMED

\begin{tabular}{lcccc} 
Operation No. & Bilateral & Unilateral & Right & Left \\
\hline 1 (all cases) & 27 & 11 & 7 & 4 \\
1 alone & 15 & 5 & 5 & 0 \\
$1+2$ & 3 & 2 & 0 & 2 \\
$1+3$ & 7 & 1 & 1 & 0 \\
$1+2+3$ & 1 & 3 & 1 & 2 \\
$1(2,3)+$ unilateral & 1 & 3 & 2 & 1 \\
lobectomy & 1 & &
\end{tabular}

'Operation no. 1 is lobotomy through the isthmus of the temporal lobe, above the temporal horn. Operation no. 2 is lobotomy through the hippocampus at the junction of the uncus with the body. Operation no. 3 is basal frontal lobotomy.

While the effect on the epilepsy was particularly good where aggressiveness was diminished, benefit was also seen in the fits in cases where the temperamental disturbance was of a different kind and was not relieved by the first operation. This is particularly seen in the cases analysed in Table IIa and summarized in Table Vb.

After the operation (no. 1) on the temporal isthmus it was observed that two types of symptoms were not always benefited. These were minor 


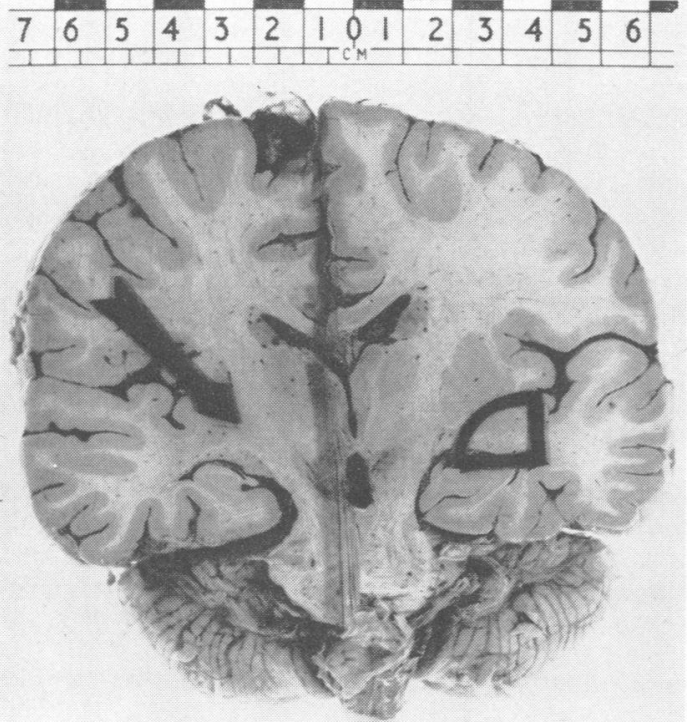

FIG. 1. Cross section of brain at two different levels. On the right is outlined the area of the section through the isthmus of the temporal lobe. Fibre tracts, the tail of the caudate nucleus, and the lowest portion of the putamen are enclosed. On the left the section is a centimetre posterior to that on the right. The arrow points to fibres passing obliquely through the internal capsule.

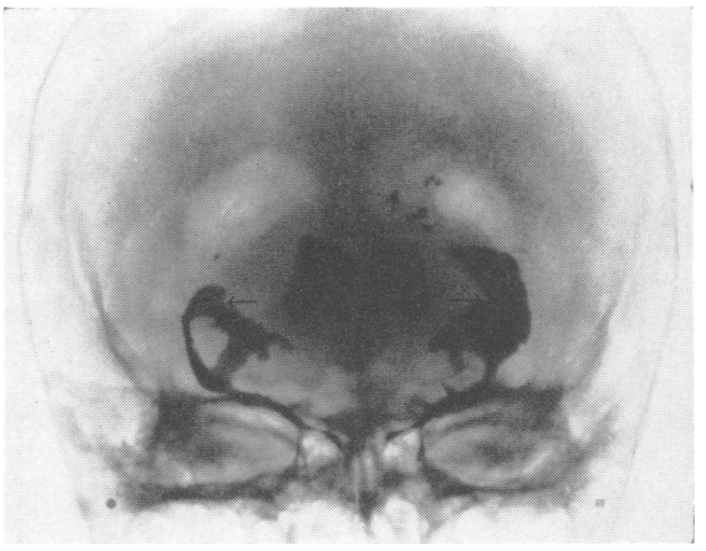

FIG. 2a. Ventriculogram with Myodil and oxygen. Postero-anterior view showing Myodil in the temporal horns. Note the shape of a fully outlined tip with the calcar avis. The arrows indicate the points from which the lateral and height coordinates are calculated.

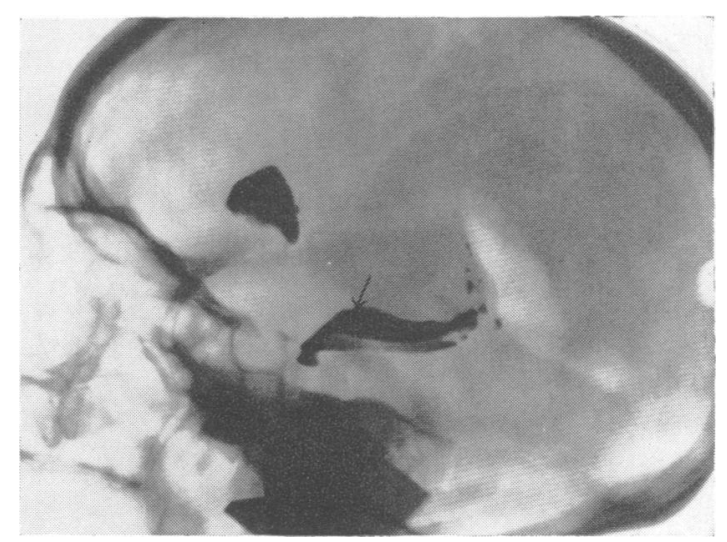

FIG. 2(b) Lateral view of the same ventriculogram. Arrow indicates the point on the nearer ventricle from which the anterior and height coordinations can be calculated. Calculation of the height from both views affords a cross check.

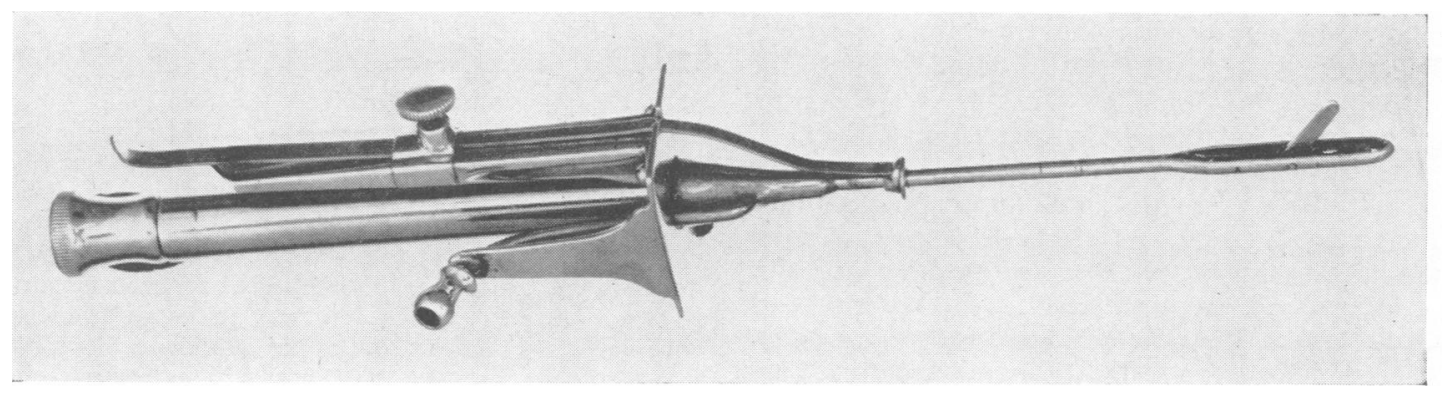

FIG. 3. The modified leucotome. 
attacks of confusion lasting a few seconds, and depression and hypochondriacal concern with trivial or imaginary complaints of diverse nature. One woman, for example, kept her head muffled in three scarves because she said exposure to cold affected it with agonizing pain and made her feel incapacitated with pain, giddiness, and dreadful malaise. Before the operation hysterical symptoms had also been present but were submerged by the main complaints of frequent attacks of psychomotor epilepsy. Where complained of afterwards, such traits had always been present before operation but after operation they frequently became comparatively and absolutely more prominent. The minor attacks of confusion often seemed to take the place of major psychomotor attacks, though they too had usually been present to some extent before operation. Attention was then directed at these minor attacks of confusion which were thought to be associated with depression. Where they were accompanied by high-voltage sharp waves focal at the nasal electrode, frontal operation (operation 3) was undertaken. Such focal discharges are normal under pentothal and are usually accompanied by truncated forms occurring synchronously at the parietal electrodes. They were especially numerous in young subjects, but when they seemed more prominent than normal for the age, they were thought in this connexion to denote petit mal. However, the results of frontal operations did not bear this out. Depression and hypochondria were greatly improved, but the minor attacks of confusion were not consistently improved and it was concluded that some of them represented minor temporal lobe attacks resembling brief periods of automatism. For these the hippocampal section was performed (operation no. 2). Early results of this procedure are encouraging, but follow-up has been too short to evaluate the procedure.

The E.E.G. recordings by depth electrodes at the time of operation seldom revealed any abnormality in the temporal isthmus as might be expected from recording from tracts, but on two occasions highvoltage sharp waves were seen, resembling the focal discharges that had been recorded from the sphenoidal leads. Stimulation in this area occasionally produced apnoea or feelings of apprehension, but usually no response. No attempt was made to search the area by multiple punctures, and indwelling deep electrodes were not used. As employed in an isolated way only to the selected points chosen for the lobotomies, the examinations by recording or stimulation at the time of operation either under local or general anaesthesia were essentially unhelpful, but an intensive study by indwelling electrodes might be more productive. The numbers of the various operations performed are shown in Table I.

\section{CASE HISTORIES}

CASE 2 R.F., aged 42, a milling machinist, had suffered from epileptic fits for 26 years. A 'very unpleasant sensation' and mental confusion were followed 10 seconds later by contractions of the lower abdomen and then loss of consciousness with generalized convulsions, occurring three or four times a week. In addition he had numerous minor attacks of confusion several times a day and longer periods of automatism about once daily during the months before admission. The head and face were badly scarred from extensive burns sustained during a fit. Depressive features with contemplation of suicide, worry, and obsessional traits led to intensive psychiatric treatment, including in-patient treatment in mental hospitals and clinics. All conservative measures failed, and his state became one of almost continuous confusion with alternating depressive and aggressive behaviour. The spectacle he presented in these attacks with his scarred face and head produced a deep and lasting impression on all who saw him. An E.E.G. showed theta activity in the right parietal area, and sphenoidal leads focal discharges independently at the two temporat bases. On 17 September 1956 a right temporal lobotom $\bar{\Phi}$ was performed (operation no. 1). After a brief period o improvement his state became as bad as before with similar symptoms. On 24 November 1956 a left tem? poral lobotomy was performed (operation no. 1). Hi condition thereafter improved dramatically, and thougg he still worried about details and was quite hypoe chondriacal about trivial complaints he did not break. down again. Post-operative testing showed performances $\vec{\oplus}$ at 'bright-average' level on the Wechsler scale and pro- $\%$ gressive matrices. He started work in March 1957 and with only short intervals between jobs has worked ever since. At one stage he worked for about six months as a factory inspector, but found this occupation too responsible and worried excessively in case he was missing faults. He became a park attendant. He still suffers from nocturnal convulsions two or three times a month, but has no diurnal attacks. If he worries excessively he may have a feeling as though he might have an attack but he can fight this off. He has been advised to return to hospital for review and possible basal frontal lobotomy but has refused.

CASE 6 B.G. aged 22, unemployed, had suffered attacks of automatism for five years with two attacks of loss of consciousness. As a child he had been slow to learn, and was backward at school, but eventually learned to read and write. Attacks consisted of lowering the head, dribbling from the mouth for about a minute, then vagueness, and on recovery amnesia for the attack: frequency about twice a month. He had tried twice to commit suicide, and was subject to attacks of ungovernable rage so that his father would not have him live in the house as he had attacked his mother in a dangerous fashion. Once he tried to burn down the house. The other members of the family were intellectually 
A new approach to unilateral and bilateral lobotomies for psychomotor epilepsy

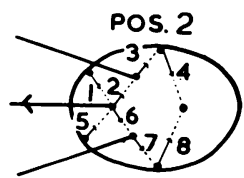

SPHENOIDAL LEADS

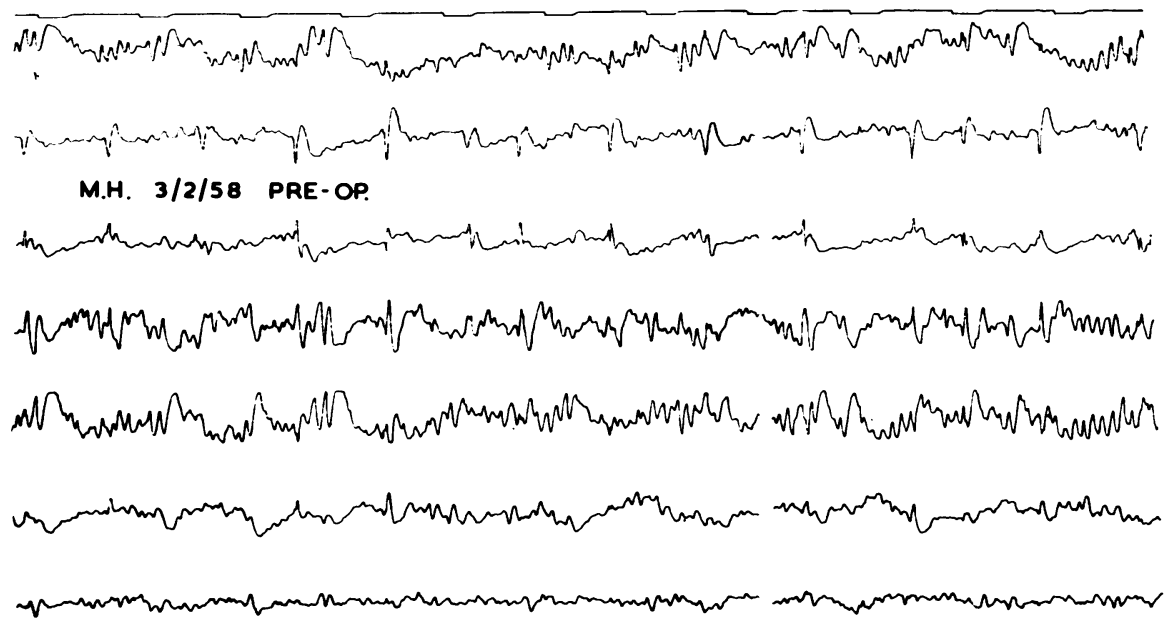

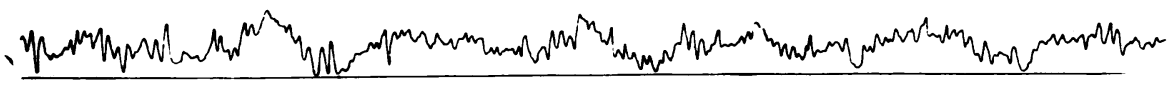

FIG. 4a. E.E.G. with sphenoidal leads showing high-voltage discharges focal at the right sphenoidal electrode and spreading in phase to the right medial frontal base, and, to a slight extent, to the left frontal and temporal bases. Such analysis is necessary in planning treatment.
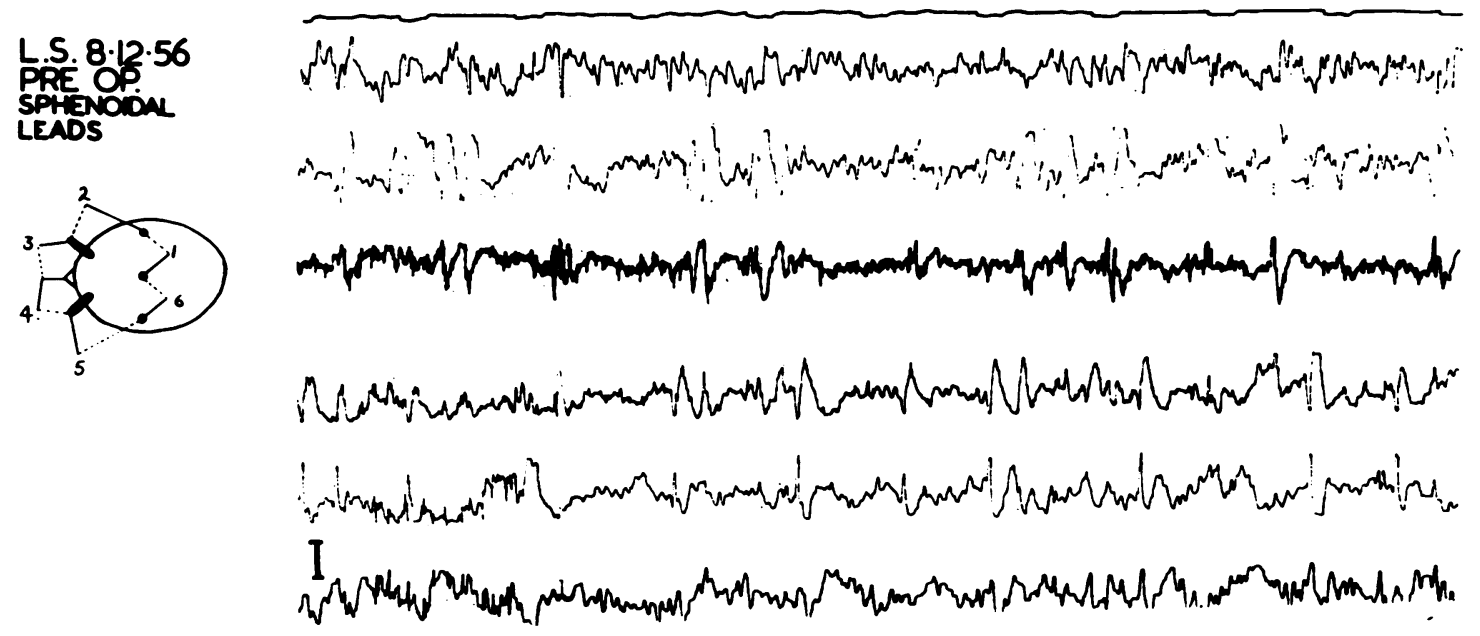

FIG. 4b. Bilateral independent high-voltage discharges focal in roughly equal numbers at the two sphenoidal electrodes. This case is unsuitable for unilateral lobectomy and only bilateral lobotomy is available on present knowledge. 
brilliant, and in the family surroundings the patient's insufficiency was particularly noticeable. An E.E.G. showed some theta activity in the right temporal region. Sphenoidal leads revealed numerous sharp waves focal at the left sphenoidal electrode with a small number of similar waves focal independently at the right sphenoidal electrode. On 6 April 1957 left temporal lobotomy was performed (operation no. 1). The frequency of attacks soon returned to the pre-operative level and the patient again attempted suicide. He was admitted to a mental hospital. In March 1958 sphenoidal leads showed some flattening of the channels centred at the right temporal base. Focal sharp waves were still present at the left sphenoidal electrode. Right temporal lobotomy was performed (operation no. 1). For six months psychomotor attacks continued, and he felt depressed but there were no further episodes of violence. Thereafter frequency of attacks steadily diminished with no recurrence of violence. At the last follow-up he had had no attacks for two years.

CASE 19 J.H., aged 16, a lathe operator, two years before admission was struck on the head by a piece of metal and briefly concussed. Before the accident he had been head boy at a secondary modern school and had developed normally. A week after the injury he began to have fits of varying types, consisting of brief lapses of consciousness without falling, grand mal beginning with clenching of the left fist but without subsequent recollection of any aura, déja-vu experiences, and automatism. After these attacks he had facial agnosia for some minutes, being unable to recognize the features of people round him, though he was otherwise correctly orientated. His behaviour changed: he was put on probation for stealing, he drank to excess, and he lost all appreciation of truth. Many times he was admitted to hospital with injuries from fits, or because of drunkenness, and for six months he was in a mental hospital. In hospital several attacks were witnessed. Between them he wandered about constantly and talked at length with circumlocutions suggestive of mild dysphasia. He stole beer, and searched other patients' lockers for tit-bits even while they looked on. An E.E.G. showed slow waves in the left temporal region. In the sphenoidal leads bilateral focal discharges were present independently at the temporal bases, more on the left. A Myodil ventriculogram revealed slight dilatation of the right temporal horn.

Psychological testing in 1957 and 1958 suggested an average general level with some superior scores. 'Just before operation he had great difficulty with a learning test, but there was some perseveration and it was thought that the difficulty was more a disturbance of thinking than of learning. There was evidence of a fluctuating difficulty in organizing speech that amounted to a mild dysphasia.' In June 1958 a bilateral temporal lobotomy was performed (operation no. 1). Hyperkinesis, verbal prolixity, and hysterical reactions to frustrations became more marked. He drank excessive amounts. His father would not allow him to be rehabilitated in a mental hospital. The boy went home and promptly absconded for some days. During the subsequent four months he had four 'absences' a month, but thereafter his attacks ceased.
Some eight months after operation during his mental hospital treatment his performance on intellectual tests was rather worse, although his learning appeared to be $\mathscr{C}$ slightly improved. By August, 1960 he was performing at a slightly better level than he had done immediately before his operation. He still did poorly on a learning test, but ${ }_{0}$ it could no longer be called really abnormal. His mild dysphasia was now scarcely manifest on testing. At this time he was working as an apprentice carpenter and attending a technical college. Social relationships were satisfactory and he had stopped thieving and excessive drinking.

CASE 23 F.S., aged 43, an interior decorator, began at the age of 19 to have grand mal. Two years previously convulsions were controlled with Mysoline but were replaced by psychomotor attacks which occurred once a week up to three times daily. An aura of auditory hallucinations, e.g., a drum beat, sound of a horn, an opening door, was followed by 'silly talk' and a sensation of queerness; on rare occasions he was incontinent of urine and faeces. In addition he had attacks of ungovernable rage, in one of which he turned his whole family into the street in the middle of the night. From being an employer of 19 men in his business he declined into an inactive member of a smaller business run by his wife and a foreman. Sphenoidat is leads showed bilateral independent high-voltage foca i discharges at the temporal bases, and some separate foca discharges at the left parietal convexity and right fronta용 base. A ventriculogram was normal. The psychologica report was of mild dysphasic errors with disordere $\$$ thought content: performance on intellectual tests wao barely average, though he had been near the top of hito $\frac{5}{\infty}$ form at school. Bilateral temporal lobotomy was per formed in September 1958 (operation no. 1). Thereaftês he insisted on going back to work immediately and withif $\tilde{\omega}^{+}$ a short time exhibited such severe paranoid traits that he was confined in a mental hospital, where he remains. Before his confinement he had a succession of fits but thereafter he has had about two minor attacks a year. His thought content continues to revolve round litigation for money he thinks is owed to him, and round misdemeanours he construes in the management of the business, which has had to be closed down.

CASE 27 M.C., aged 26, a housewife, from the age of 14 (after the menarche) suffered from psychomotor attacks four times daily during menstrual periods and once or twice during the rest of the month. She had been free of attacks during and for some months after a pregnancy, four years previously. She had severe bronchopneumonia as a baby. She was amnesic for the attacks, but during them she grunted or moaned, and stood clutching any available object for a few seconds. Thereafter she was confused for about a minute. On occasions there was an aura of déjà $v u$ with a dream-like quality. About one attack in four progressed to a generalized convulsion. Between attacks she was depressed and irritable. There was considerable marital disharmony. An E.E.G. showed right temporal $3 / \mathrm{s}$ focal discharges and some bilateral theta activity. In the sphenoidal leads there were highvoltage sharp waves focal at each sphenoidal electrode, 
and also bilateral high-voltage discharges focal at the mid-line probably in the frontal base. In the ventriculogram the tip of the right temporal horn was slightly dilated. Psychological testing showed average intelligence with possibly slight spatial difficulties. Learning was only fair but was probably within normal limits. Bilateral temporal lobotomy was performed in May 1959 (operation no. 1). Thereafter she showed marked depression and hypochondria. After the operation the attacks were unimproved and in March 1960 she had a basal frontal lobotomy (operation no. 3). Her attacks continued as before, though her depression was less, and she took a greater interest in outside activities. She was admitted for review in June 1961. Sphenoidal leads still had bilateral independent foci at the temporal bases with insignificant discharges at the frontal bases, and a very infrequent discharge at the right lateral temporal electrode. It was thought that she might be suitable for hippocampal section but she had had such a good spell in the preceding six months, with the last seven weeks completely free of attacks, that operation was not advised at that time. The attacks then consisted of an aura of a faint smell with a feeling of unreality. This was followed by a dreamy state when she might see faces or hear voices. She did not lose consciousness, but on recovery after a few minutes felt drowsy for about half an hour.

CASE 30 G.S., aged 36, an engineer, suffered from major convulsions since the age of 6 , eight months after an attack of pneumonia with empyema. There was a history of epigastric aura, leading to automatism with violence or to convulsions. The convulsions occurred in bouts every two months or so, each bout consisting of six or eight fits over about 36 hours. His memory had never been good but had deteriorated over the previous four months. In addition he had episodes of ungovernable rage when he was involved in violence. Once he fought a workmate and broke several of his opponent's ribs. The rages were most liable to occur during the periods when he was having fits. One brother suffered from epilepsy. Blood pressure was $235 / 145 \mathrm{~mm}$. Hg. He complained of right temporal headaches aggravated by noise. A radiograph of the chest showed old tuberculous fibrosis and calcification at the right apex, and synostosis of the right ninth and tenth ribs consistent with empyema in infancy. Psychological tests revealed equivocal indication of parietal dysfunction. An E.E.G. showed right temporal focal discharges. On sphenoidal lead examination there were focal discharges at the right temporal base. In October 1959 a right temporal and basal frontal lobotomy were performed (operations nos. 1 and 3). The patient complained bitterly of headaches after this procedure. Investigation of the hypertension showed normal urine and urinary catecholamines. An intravenous pyelogram was normal. The patient did not tolerate hypotensive drugs, and discontinued them.

In January 1961 he was re-admitted because of persistence of fits, though temperament was improved. A right temporal lobectomy was performed. During the following two months he had only one attack at night. Temperament was greatly improved. Since then he has not turned up at routine follow-up though it has been ascertained that he is still working. His state of health is not known.

CASE 1 M.W., a woman aged 31 years, had had minor psychomotor and convulsive seizures since the age of 18 months, and aggressive outbursts, especially since leaving school where she did moderately well. Her thought content was paranoid. She had a bilateral temporal lobotomy (operation no. 1) in August 1956. Intermittent bouts of fits followed, during which she became overactive and destructive requiring admission to a mental hospital. This tendency diminished. Now she has only one episode of aggression in a year, with four generalized seizures a year. She is still paranoid and confined to a mental hospital.

CASE 4 M.P., a woman aged 35 years, had bilateral mastoid operations at the age of 6 years. Her personality changed after operation ('a little devil'). After warning of sweating, hot and cold feelings, fits of uncontrollable rage followed. Déjà-vu phenomena were experienced. Paranoid attitude was marked. There was slight dilatation of the temporal horn of the right lateral ventricle, bilateral focal discharges in sphenoidal leads. Bilateral temporal lobotomy (operation no. 1) was performed in December 1956. She was admitted to a mental hospital a month later, with bouts of disordered behaviour. Gradually she quietened to a dull, emotionally flat state which slowly improved but she remains in the mental hospital, showing a rather inadequate personality with paranoid features. There have been no epileptic seizures and no bouts of aggression for some years.

CASE 7 A.A., a man aged 40, had generalized convulsions for eight years, at first with an aura of epigastric discomfort now without remembered warning. Minor attacks of fluttering in the epigastrium were followed by a sensation of unreality. He was very depressed, especially after each fit. An E.E.G. showed a well-marked basal temporal focus spreading to the frontal base. On 4 May 1957 a right temporal lobotomy (operation no. 1) was performed with short attacks of automatism persisting and he remained depressed. On 22 April 1959 a right frontal basal lobotomy (operation no. 3) was performed but he continued to have short attacks, now with falling and unconsciousness, with no warning and no convulsions. On 17 December 1960 a right hippocampotomy (operation no. 2) was performed. Attacks persisted, but they were short without falling. On 12 April 1962 right temporal lobectomy was performed. Follow-up has been insufficient for assessment. The E.E.G. abnormality has remained unilateral throughout.

CASE 9 N.E., a man aged 34 years, had convulsions for 10 years following a mild head injury. Three generalized convulsions were witnessed in hospital. He had many hysterical features and hypochondria, and was invalided out of the Army as hysteric. He receives a full pension. Sphenoidal leads showed focal discharges at both sphenoidal electrodes. On 17 June 1957 bilateral temporal lobotomy (operation no. 1) was performed. The patient still had numerous hypochondriacal complaints 
and depression and basal frontal discharges on E.E.G. On 10 June 1961 basal frontal lobotomy was performed, resulting in less depression but the patient was still hypochondriacal. He is unemployed and the family has broken up. He has had no convulsions since the first operation.

CASE 13 L.G., a man aged 51 years, had generalized convulsions, preceded by aura of unpleasant smell, twice a month for five years following a minor head injury at work. He lost his right eye in an accident in infancy. He had signs of an old empyema at the left base of the chest. Sphenoidal leads showed independent spike-andwave discharges at the two sphenoidal electrodes. On 2 October 1957 bilateral temporal lobotomy (operation no. 1) was performed. He had two generalized attacks in the first year, then was free of attacks till 1960 when he had pneumonia, and had a convulsion during the fever. Since then he had had two major attacks a year, and numerous minor 'attacks' during which he feels 'hazy' and lies down, complaining of pain above the socket of the artificial eye and worrying about his eyesight (no abnormality demonstrable in this). He complains of poor memory when he is worried. He is waiting to come in for observation and review. He has been unemployed for many years.

CASE 14 J.W., a woman aged 34 years, has had fits since she was 16 , at first generalized convulsions but of recent years numerous minor psychomotor attacks, with major psychomotor and convulsive attacks during the week before menstruation. She is emotionally unstable in relation to numerous attacks of confusion occurring several times each day. Sphenoidal leads showed bilateral independent focal discharges at sphenoidal electrodes. On 2 November bilateral temporal lobotomy (operation no. 1) was performed. After freedom for three months, seizures returned and have remained at two convulsions, one major psychomotor attack, and three minor attacks a month before or after the menstrual period. She has been advised to return for review and hippocampotomy but her husband wrote that she was so greatly improved, running the house, joining social activities, and keeping stable emotionally that he was not willing to agree to further hospital treatment.

CASE 15 D.M., a man aged 37 years, received a penetrating shell wound in 1944, tracking with scattered metallic fragments through the left frontal sinus to the left occipital region. He had a right hemiplegia and dysphasia, and pain and postural sense were impaired. He had right homonymous hemianopia, and minor attacks with an aura of compulsive memory, several times a day. Convulsive seizures without remembered warning occurred once or twice a month. Sphenoidal leads showed a focal discharge at the left sphenoidal electrodes, E.E.G. flattening with slow waves over the rest of the hemisphere. On 9 November 1957 left temporal lobotomy (operation no. 1) was performed but the attacks were unchanged. On 9 September 1961 a left hippocampotomy (operation no. 2) was performed without effecting any improvement in the seizures.
CASE 17 D.M., a man aged 39 years, had generalized $Z$ convulsions for more than 12 years. For the last two years he had psychomotor attacks and short generalized $O$ seizures preceded by an aura of shimmering lights. He had a violent temper, and beat his wife frequently so that the police were called. The wife broke down and required 0 psychiatric treatment, including E.C.T. Sphenoidal leads showed independent focal discharges at sphenoidal electrodes. On 14 March 1958 a bitemporal lobotomy (operation no. 1) was performed. Thereafter the patient $\therefore$ was depressed, and the attacks were milder, shorter, but $\overrightarrow{\overline{\vec{D}}}$ more numerous. There were E.E.G. abnormalities at the frontal bases as well as the sphenoidal areas. On 3 June 1959 a bilateral basal frontal lobotomy (operation no. 3) was performed. Minor psychomotor attacks and genera- $\bar{s}$ lized convulsions persist, though psychomotor attacks are milder and less frequent. He still has these minor attacks more when worried and tense. His temperament is vastly improved, and he has not shown any violence $\vec{O}$ since the first operation.

\section{OVERALL RESULTS}

The overall results are presented in Tables II to IV in which the methods of treatment, frequency of or attacks, and effects on temperamental changes are summarized. In Tables IV to VIII the figures fror of Tables II to IV are collated. One unexpected featurfo 음 was the substantial, though not spectacular, inf provement in grand mal attacks. Even when presen these were usually greatly shortened, and ofteg were unaccompanied by clonic convulsions althoug $\frac{c}{\rho}$ loss of consciousness, falling, and tonic spasm. might still be present. The focal abnormalities iñ the sphenoidal leads were not abolished though they were usually diminished in number. Delayed benefit was seen in several cases, especially in young people.

A disappointing feature was the work record. Previously unemployed patients often, though not always, stayed unemployed. Those who had been at work usually continued, but tended to gravitate to less arduous work. They seemed to have lost some of their stimulus to work at the same time as they lost their bad temper, and even fewer difficulties in the form of attacks now sufficed to dissuade them from effort. Employers too might keep their jobs open pending operation, but once that had been performed the patient necessarily gravitated to the correct working level. Occasionally hypochondriacal worries or feelings of tension interfered with work, especially where responsibility was involved. The temperamental effects were mainly beneficial, producing most gratitude from spouses who had previously been viciously assaulted. They were not uniformly good, however. Apart from depression, hysterical symptoms and hypochondria, which might be regarded as frontal lobe overpreponderance and paranoic trends, were not improved. They were less 
TABLE II

RESULTS FROM BILATERAL OPERATIONS IN NON-PSYCHOTIC PATIENTS

Case Lobotomies

No. $\quad$ 1
Lobec

Number of Seizures per Year

\begin{tabular}{|c|c|c|c|c|c|}
\hline \multicolumn{2}{|c|}{ Grand Mal } & \multicolumn{4}{|c|}{ Psychomotor } \\
\hline Before & After & Minor & & Major & \\
\hline tion & tion & $\begin{array}{l}\text { Before } \\
\text { Opera- } \\
\text { tion }\end{array}$ & $\begin{array}{l}\text { After } \\
\text { Opera- } \\
\text { tion }\end{array}$ & $\begin{array}{l}\text { Before } \\
\text { Opera- } \\
\text { tion }\end{array}$ & $\begin{array}{l}\text { After } \\
\text { Opera- } \\
\text { tion }\end{array}$ \\
\hline
\end{tabular}

Mental State

Before Operation

After Operation

Date of

Last Follor

\begin{tabular}{|c|c|c|c|c|c|c|c|c|c|c|c|c|}
\hline 2 & $\begin{array}{l}\text { R. } \\
\text { 17. } 9.56 \\
\text { L. } \\
24.11 .56\end{array}$ & & & 150 & 36 & $\begin{array}{l}\text { Almost } \\
\text { con- } \\
\text { tinuous }\end{array}$ & t & 350 & 0 & Confused, mania & $\begin{array}{l}\text { Great improvement, } \\
\text { anxious and tense but } \\
\text { controlled }\end{array}$ & 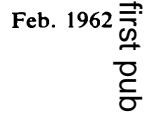 \\
\hline 5 & $\begin{array}{l}\text { Bilateral } \\
21.1 .57\end{array}$ & & & 2 & 0 & 0 & 0 & 4 & 0 & $\begin{array}{l}\text { Outbursts of violence, } \\
\text { depression, hypo- } \\
\text { chondria }\end{array}$ & $\begin{array}{l}\text { Improved, no violence, } \\
\text { but still hypochondria }\end{array}$ & Aug. $1959 \frac{\text { ज. }}{\frac{\text { के }}{\text { อ }}}$ \\
\hline 6 & $\begin{array}{l}\text { L. } \\
6.4 .57 \\
\text { R } \\
22.3 .58\end{array}$ & & & 0 & 0 & 0 & 0 & 24 & 0 & $\begin{array}{l}\text { Attacks of rage, } \\
\text { depression }\end{array}$ & $\begin{array}{l}\text { Improved, stable in } \\
\text { affect }\end{array}$ & 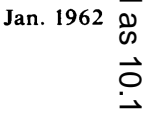 \\
\hline 8 & $\begin{array}{l}\text { Bilateral } \\
27.5 .57\end{array}$ & & $\begin{array}{l}\text { Bilateral R. } \\
25.3 .60 \\
28.2 .59\end{array}$ & $>1,000$ & 12 & 50 & 0 & 0 & 0 & $\begin{array}{l}\text { Depressed, occasional } \\
\text { aggression }\end{array}$ & $\begin{array}{l}\text { Depressed, no aggression, } \\
\text { poor concentration, poor } \\
\text { memory }\end{array}$ & Nov. 1961 \\
\hline 9 & $\begin{array}{l}\text { Bilateral } \\
17.6 .57\end{array}$ & & $\begin{array}{l}\text { Bilateral } \\
10.6 .61\end{array}$ & 0 & 0 & 0 & 0 & 24 & 0 & $\begin{array}{l}\text { Hysterical behaviour, } \\
\text { hypochondria }\end{array}$ & No improvement & June 1962 ఫِ \\
\hline $1 i$ & $\begin{array}{l}\text { Bilaterai } \\
8.7 .57\end{array}$ & & & 12 & 12 & 0 & 0 & 12 & 0 & $\begin{array}{l}\text { Attacks of rage and } \\
\text { aggression }\end{array}$ & Great improvement & Sept. 1960 م \\
\hline 2 & $\begin{array}{l}\text { Bilateral } \\
30.9 .57\end{array}$ & & $\begin{array}{l}\text { Bilateral } \\
16.3 .57\end{array}$ & 360 & 240 & 0 & 50 & 0 & 0 & $\begin{array}{l}\text { Irritability and } \\
\text { aggression }\end{array}$ & $\begin{array}{l}\text { Improvement, no } \\
\text { aggression }\end{array}$ & May 19马ु \\
\hline 13 & $\begin{array}{l}\text { Bilateral } \\
2.10 .57\end{array}$ & & & 24 & 2 & 0 & $\begin{array}{l}360 \\
(?)\end{array}$ & 0 & 0 & $\begin{array}{l}\text { Irritability and } \\
\text { aggression }\end{array}$ & Great improvement & July 19욤 음 \\
\hline 14 & $\begin{array}{l}\text { Bilateral } \\
2.11 .57\end{array}$ & & & 100 & 24 & $>1,000$ & 36 & 100 & 12 & $\begin{array}{l}\text { Emotionally unstable, } \\
\text { depressed, irritable }\end{array}$ & $\begin{array}{l}\text { Improved, stable and } \\
\text { cheerful }\end{array}$ & March \\
\hline 17 & $\begin{array}{l}\text { Bilateral } \\
15.3 .58\end{array}$ & & $\begin{array}{l}\text { Bilateral } \\
3.6 .59\end{array}$ & 26 & 26 & 75 & 75 & 24 & 0 & $\begin{array}{l}\text { Bouts of uncontrol- } \\
\text { lable aggression and } \\
\text { violence }\end{array}$ & Great improvement & 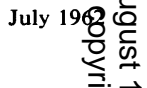 \\
\hline . & $\begin{array}{l}\text { Bilateral } \\
8.5 .58\end{array}$ & & $\begin{array}{l}\text { Bilateral } \\
7.11 .60\end{array}$ & 100 & 2 & 0 & $\begin{array}{l}100 \\
(?)\end{array}$ & 50 & 0 & $\begin{array}{l}\text { Hysterical bouts of } \\
\text { agitated confusion, } \\
\text { many suicidal attempts }\end{array}$ & $\begin{array}{l}\text { Great improvement, } \\
\text { still hysterical features }\end{array}$ & 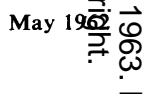 \\
\hline .9 & $\begin{array}{l}\text { Bilateral } \\
16.6 .58\end{array}$ & & & 150 & 0 & 700 & 0 & 100 & 0 & Delinquency & $\begin{array}{l}\text { Improved, stable and } \\
\text { working }\end{array}$ & Sept. $1960 \bigcirc$ \\
\hline 21 & $\begin{array}{l}\text { Bilateral } \\
21.7 .58\end{array}$ & & & 6 & 0 & 24 & 100 & 24 & 0 & $\begin{array}{l}\text { Uncontrollable rage } \\
\text { and violence, paranoid } \\
\text { features }\end{array}$ & $\begin{array}{l}\text { No further aggression, } \\
\text { still mildly paranoid }\end{array}$ & 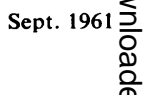 \\
\hline 22 & $\begin{array}{l}\text { Bilateral } \\
2.8 .58\end{array}$ & $\begin{array}{l}\text { Bilateral } \\
15.10 .60\end{array}$ & & 50 & 0 & $>1,000$ & 30 & 0 & 0 & $\begin{array}{l}\text { Hypochondria, hysteria, } \\
\text { confusion }\end{array}$ & $\begin{array}{l}\text { Hysteria and hypo- } \\
\text { chondria }\end{array}$ & May $1962 \stackrel{\mathbb{D}}{\frac{2}{\sqrt{2}}}$ \\
\hline 24 & $\begin{array}{l}\text { R. } \\
17.12 .56 \\
\text { L. } \\
22.4 .57\end{array}$ & & $\begin{array}{l}\text { Bilateral } \\
9.1 .60\end{array}$ & 12 & 100 & $>1,000$ & $>1,000$ & $\begin{array}{l}\text { Almost } \\
\text { con- } \\
\text { tinuous } \\
>1,000\end{array}$ & 0 & $\begin{array}{l}\text { Confused, irritable, } \\
\text { depressed }\end{array}$ & $\begin{array}{l}\text { No improvement though } \\
\text { less confused, showing } \\
\text { paranoid features }\end{array}$ & 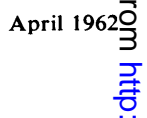 \\
\hline 26 & $\begin{array}{l}\text { R. } \\
1.12 .58 \\
\text { L. } \\
12.11 .60\end{array}$ & $\begin{array}{l}\text { Bilateral } \\
12.11 .60\end{array}$ & & 1 & 0 & 150 & 70 & 0 & 0 & Dull and withdrawn & I.S.Q., paranoid ideas & 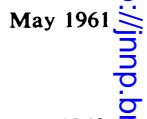 \\
\hline 2 & $\begin{array}{l}\text { Bilateral } \\
27.5 .59\end{array}$ & & $\begin{array}{l}\text { Bilateral } \\
14.3 .60\end{array}$ & 12 & 0 & 50 & 0 & 120 & 50 & $\begin{array}{l}\text { Depressed and irritable, } \\
\text { marital disharmony }\end{array}$ & Improved & Jan. 1962 그. \\
\hline 1 & $\begin{array}{l}\text { R. } \\
16.1 .60 \\
\text { L. } \\
17.6 .62\end{array}$ & $\begin{array}{l}\text { Bilateral } \\
17.6 .62\end{array}$ & $\begin{array}{l}1 \mathrm{R} . \\
16.1 .60\end{array}$ & 720 & $?$ & 360 & $?$ & 360 & $?$ & $\begin{array}{l}\text { Quarrelsome, not } \\
\text { violent }\end{array}$ & Not yet known & 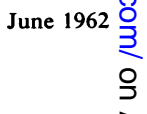 \\
\hline 34 & $\begin{array}{l}\text { Bilateral } \\
14.5 .60\end{array}$ & & & 360 & 100 & 360 & 360 & $\mathbf{0}$ & 0 & No abnormality & I.S.Q. & June 1962 을. \\
\hline 35 & $\begin{array}{l}\text { Bilateral } \\
6.8 .60\end{array}$ & $\begin{array}{l}\text { Bilateral } \\
6.8 .60\end{array}$ & & 50 & 1 & 0 & $>1,000$ & $>1,000$ & $\mathbf{0}$ & $\begin{array}{l}\text { Quarrelsome, sometimes } \\
\text { violent }\end{array}$ & Greatly improved & April $1962 \overline{\mathrm{N}}$ \\
\hline $\begin{array}{l}37 \\
-\end{array}$ & $\begin{array}{l}\text { Bilateral } \\
10.2 .61\end{array}$ & & & 100 & 12 & 360 & $\mathbf{0}$ & 360 & 50 & $\begin{array}{l}\text { Irritability and } \\
\text { violence }\end{array}$ & $\begin{array}{l}\text { Great improvement, lost } \\
\text { bad temper completely }\end{array}$ & Aug. $1961 \mathrm{~N}$ \\
\hline \multicolumn{13}{|c|}{ Operation numbers as in Table $I$. } \\
\hline
\end{tabular}


TABLE IIa

ANALYSIS OF INTERMEDIATE STATES IN CERTAIN CASES IN TABLE II WITH MULTIPLE OPERATIONS

\begin{tabular}{|c|c|c|c|c|c|c|c|c|c|c|}
\hline \multirow{4}{*}{$\begin{array}{l}\text { Case } \\
\text { No. }\end{array}$} & \multicolumn{3}{|c|}{ Lobotomies } & \multirow{4}{*}{$\begin{array}{l}\text { Lobec- } \\
\text { tomy }\end{array}$} & \multicolumn{6}{|c|}{ Number of Seizures per Year } \\
\hline & \multirow[t]{3}{*}{1} & \multirow[t]{3}{*}{2} & \multirow[t]{3}{*}{3} & & \multicolumn{2}{|c|}{ Grand Mal } & \multicolumn{4}{|c|}{ Psychomotor } \\
\hline & & & & & Before & After & Minor & & Major & \\
\hline & & & & & tion & $\begin{array}{l}\text { tion } \\
\text { tion }\end{array}$ & $\begin{array}{l}\text { Before } \\
\text { Opera- } \\
\text { tion }\end{array}$ & $\begin{array}{l}\text { After } \\
\text { Opera- } \\
\text { tion }\end{array}$ & $\begin{array}{l}\text { Before } \\
\text { Opera- } \\
\text { tion }\end{array}$ & $\begin{array}{l}\text { After } \\
\text { Opera- } \\
\text { tion }\end{array}$ \\
\hline
\end{tabular}
Mental State

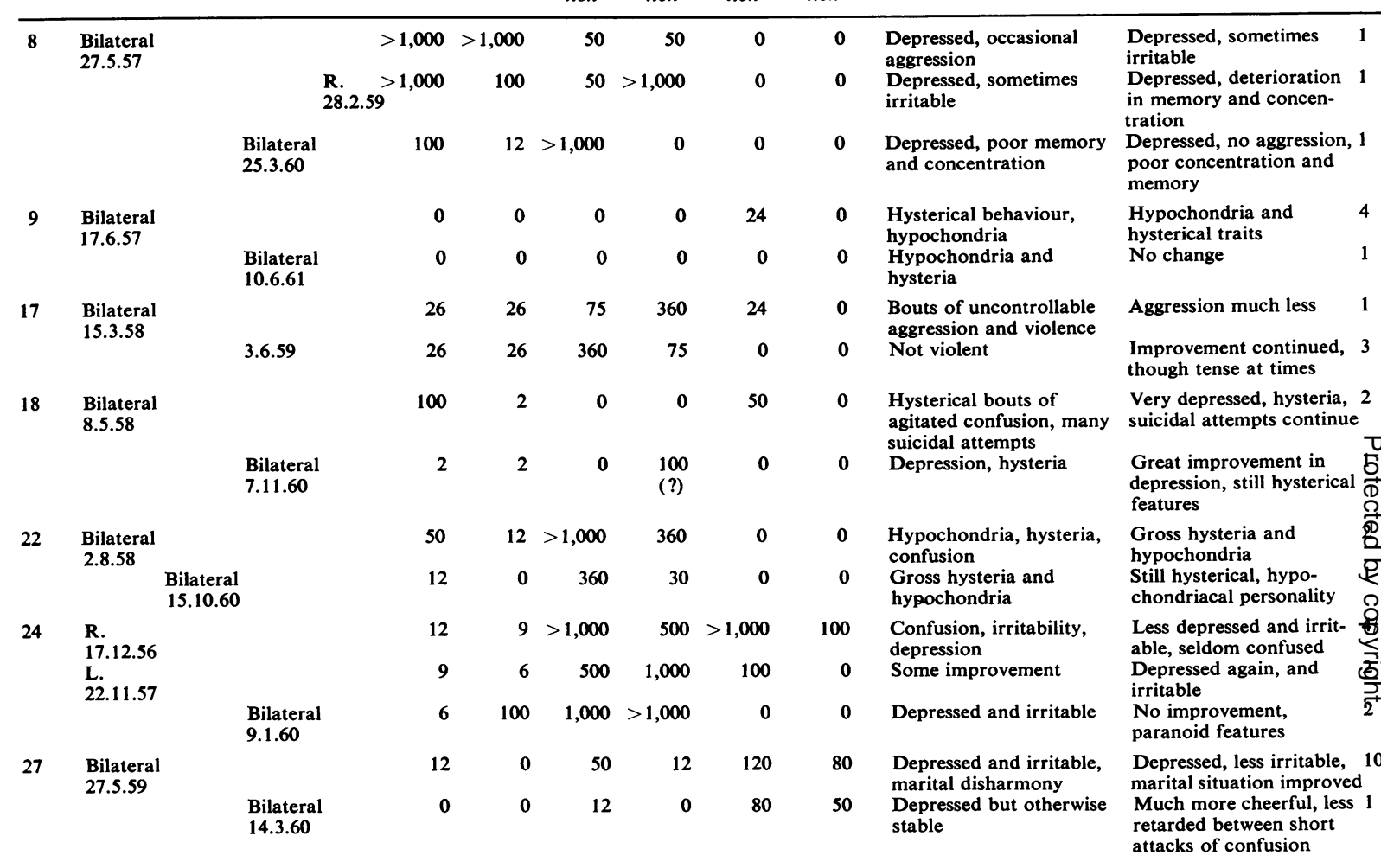

likely to be accompanied by violence, but might still be accompanied by considerable bitterness and cold unpleasantness. It was possible to detect in the preoperative personality those features which were likely to persist and even increase with the different operative procedures, and apart from the symptoms referable purely to the epileptic process, an important prognostic consideration was the preoperative or even pre-morbid character as shown by the work record, career and habits, and as mirrored in the opinions of relatives and friends.

The effect on intellectual performance of the bilateral operations in the temporal isthmus was investigated by Mr. Peter Clarke pre-operatively in three cases, pre-operatively and post-operatively in six, and post-operatively in four others. Five unilateral cases were also examined for psychometric performance of difficult feats of recent memory.

Most of the defects were mild, and it was impossible to be certain that they represented a change due to disease because no corresponding pre-morbid assessments were available. However, assessment of pre-morbid performance at school or at work led to the conclusion that they did represent an intellectual deterioration, probably due to the same cause that produced the epilepsy. Reassessment after bilateral temporal lobotomy did not in any case reveal significant worsening in the intellectual deficit, and frequently performance was improved.

The effect of the basal frontal lobotomy consisted of a lightening of mood, a slightly more carefree attitude to the disease, and an exaggeration of any paranoic traits.

Bilateral hippocampal section at the level employed did not produce any detectable permanent change in memory. One patient had a temporary 
TABLE III

RESULTS OF UNILATERAL OPERATIONS IN NON-PSYCHOTIC AND OF BILATERAL

OPERATIONS IN PSYCHOTIC PATIENTS

Case
No. $\begin{array}{lll}\text { Lobotomies } & & \begin{array}{c}\text { Lobec- } \\ \text { tomy }\end{array}\end{array}$

'on-psychotic patients
Number of Seizures per Year

\begin{tabular}{|c|c|c|c|c|c|}
\hline \multicolumn{2}{|c|}{ Grand Mal } & \multicolumn{4}{|c|}{ Psychomotor } \\
\hline \multirow{2}{*}{$\begin{array}{l}\text { Before } \\
\text { Opera- } \\
\text { tion }\end{array}$} & \multirow{2}{*}{$\begin{array}{l}\text { After } \\
\text { Opera- } \\
\text { tion }\end{array}$} & Minor & & Major & \\
\hline & & $\begin{array}{l}\text { Before } \\
\text { Opera- } \\
\text { tion }\end{array}$ & $\begin{array}{l}\text { After } \\
\text { Opera- } \\
\text { tion }\end{array}$ & $\begin{array}{l}\text { Before } \\
\text { Opera- } \\
\text { tion }\end{array}$ & $\begin{array}{l}\text { After } \\
\text { Opera- } \\
\text { tion }\end{array}$ \\
\hline
\end{tabular}

Mental State

Before Operation(s) After Operation $(s)$

Date Follow-ung

\begin{tabular}{|c|c|c|c|c|c|c|c|c|c|c|c|c|c|}
\hline 3 & $\begin{array}{l}\text { R. } \\
10.12 .56\end{array}$ & & & & 150 & 0 & 150 & 36 & 0 & $\mathbf{0}$ & $\begin{array}{l}\text { High grade defective, } \\
\text { amiable }\end{array}$ & I.S.Q. & May $19 \overline{\frac{6}{2}}$ \\
\hline 7 & $\begin{array}{l}\text { R. } \\
4.5 .57\end{array}$ & $\begin{array}{l}\text { R. } \\
17.12 .60\end{array}$ & $\begin{array}{l}\text { R. } \\
22.4 .59\end{array}$ & $\begin{array}{l}\text { R. } \\
12.4 .62\end{array}$ & 1 & $?$ & 120 & $?$ & $\mathbf{0}$ & $?$ & Depressed after attacks & $\begin{array}{l}\text { Euphoric, not yet fol- } \\
\text { lowed-up }\end{array}$ & May $19 \overline{\frac{\overline{2}}{\vec{D}}}$ \\
\hline-10 & $\begin{array}{l}\text { R. } \\
29.6 .57\end{array}$ & & & & 12 & 2 & $\mathbf{0}$ & $\mathbf{0}$ & 24 & 0 & $\begin{array}{l}\text { Bouts of rage and } \\
\text { aggression }\end{array}$ & Improved & June 15 \\
\hline 5 & $\begin{array}{l}\text { L. } \\
10.2 .58\end{array}$ & $\begin{array}{l}\text { L. } \\
9.9 .61\end{array}$ & & & 24 & 24 & 1,000 & 1,000 & 0 & 0 & $\begin{array}{l}\text { Normal apart from mild } \\
\text { depression }\end{array}$ & I.S.Q. & Jan. 19 \\
\hline 25 & $\begin{array}{l}\text { R. } \\
2.2 .59\end{array}$ & & & & 0 & $\mathbf{0}$ & 100 & 200 & 12 & 0 & $\begin{array}{l}\text { Confused, agitated, } \\
\text { depressed }\end{array}$ & Much improved & Sept. 1 \\
\hline 28 & $\begin{array}{l}\text { L. } \\
1.6 .59\end{array}$ & $\begin{array}{l}\text { L. } \\
21.11 .60\end{array}$ & $\begin{array}{l}\text { L. } \\
30.11 .60\end{array}$ & & $\mathbf{0}$ & 0 & $>1,000$ & 96 & 120 & 0 & $\begin{array}{l}\text { Depressed, confused, } \\
\text { agitated }\end{array}$ & Much improved & Nov. 1 \\
\hline 29 & $\begin{array}{l}\text { R. } \\
15.6 .59\end{array}$ & & & & 48 & 12 & 24 & $\mathbf{0}$ & 0 & $\mathbf{0}$ & Mildly unstable & I.S.Q. & May \\
\hline$m$ & $\begin{array}{l}\text { R. } \\
23.10 .59\end{array}$ & & $\begin{array}{l}\text { R. } \\
23.10 .59\end{array}$ & $\begin{array}{l}R . \\
28.1 .61\end{array}$ & 50 & $? 6$ & 0 & $? 0$ & 50 & $? 0$ & $\begin{array}{l}\text { Uncontrollable rages with } \\
\text { violence }\end{array}$ & Improved & Mar. \\
\hline 12 & $\begin{array}{l}\text { L. } \\
30.1 .60\end{array}$ & $\begin{array}{l}\text { L. } \\
12.12 .60\end{array}$ & $\begin{array}{l}\text { L. } \\
30.1 .60\end{array}$ & $\begin{array}{l}\text { L. } \\
6.11 .61\end{array}$ & 24 & $? 0$ & $>1,000$ & $? 0$ & $\mathbf{0}$ & $? 0$ & $\begin{array}{l}\text { Quarrelsome, not } \\
\text { violent }\end{array}$ & $\begin{array}{l}\text { Improved to date, not } \\
\text { finally known }\end{array}$ & Feb. \\
\hline 38 & $\begin{array}{l}\text { L. } \\
1.10 .60\end{array}$ & $\begin{array}{l}\text { L. } \\
1.10 .60\end{array}$ & & & 120 & $\mathbf{0}$ & 50 & 50 & 0 & $\mathbf{0}$ & Moody and irritable & Improved & July \\
\hline \multicolumn{14}{|c|}{ Psychotic patients } \\
\hline 1 & $\begin{array}{l}\text { Bilateral } \\
\text { 4.8.56 }\end{array}$ & & & & 100 & 4 & 100 & 0 & $\mathbf{0}$ & 0 & Paranoid and aggressive & $\begin{array}{l}\text { Not so aggressive, still } \\
\text { paranoid }\end{array}$ & Mayz \\
\hline 4 & $\begin{array}{l}\text { Bilateral } \\
15.12 .56\end{array}$ & & & & $\mathbf{0}$ & $\mathbf{0}$ & 100 & $\mathbf{0}$ & 70 & 0 & Bouts of rage, paranoia & $\begin{array}{l}\text { Improved, no aggression, } \\
\text { paranoid }\end{array}$ & \\
\hline ; & $\begin{array}{l}\text { Bilateral } \\
10.2 .58\end{array}$ & & & & $>1,000$ & $>1,000$ & $>1,000$ & $>1,000$ & $\mathbf{0}$ & 0 & $\begin{array}{l}\text { Paranoid, aggressive, } \\
\text { confused }\end{array}$ & I.S.Q. & Nov. \\
\hline 23 & $\begin{array}{l}\text { Bilateral } \\
27.9 .58\end{array}$ & & & & 4 & $\mathbf{0}$ & 360 & 3 & $\mathbf{0}$ & 0 & $\begin{array}{l}\text { Paranoid, violent, un- } \\
\text { governable rages }\end{array}$ & $\begin{array}{l}\text { Still paranoid but no } \\
\text { longer violent }\end{array}$ & May \\
\hline 33 & $\begin{array}{l}\text { R. } \\
13.2 .60 \\
\text { L. } \\
10.10 .60\end{array}$ & $\begin{array}{l}\text { Bilateral } \\
10.10 .60\end{array}$ & 13.2 & & $>1,000$ & 300 & 0 & $\mathbf{0}$ & 0 & $\mathbf{0}$ & Depressed and resentful & Paranoid & Nov. \\
\hline B6 & $\begin{array}{l}\text { Bilateral } \\
\text { 7.9.60 }\end{array}$ & & & & $\mathbf{0}$ & $\mathbf{0}$ & $\mathbf{0}$ & 0 & 360 & 360 & $\begin{array}{l}\text { Aggressive, mental } \\
\text { deterioration }\end{array}$ & $\begin{array}{l}\text { ? Schizophrenia, } \\
\text { 'deteriorated epileptic' }\end{array}$ & Sept. \\
\hline \multicolumn{14}{|c|}{ Unilateral operation in one psychotic patient } \\
\hline 20 & $\begin{array}{l}\text { R. } \\
8.7 .58\end{array}$ & & & & 200 & 200 & 0 & $\mathbf{0}$ & 0 & 0 & Aggressive paranoid & $\begin{array}{l}\text { Less aggression but still } \\
\text { paranoid }\end{array}$ & Apri \\
\hline
\end{tabular}

TABLE IV

SUMMARY OF RESULTS FROM BILATERAL OPERATIONS IN NON-PSYCHOTIC CASES

Tw'enty-one Cases

Grand Mal

Psychomotor

Temperamental Disturbance

Minor Major

Present before operation

Attacks absent post-operatively (previously present) Improved

Unchanged

Worse

Not yet known

19
6
9
2
1
1

$\begin{array}{rr}12 & 15 \\ 5 & 11 \\ 2 & 3 \\ 3 & 0 \\ 5^{1} & 0 \\ 1 & 1\end{array}$

IIncluding four cases in which minor attacks appeared to replace major ones where minor attacks had not been reported previously.

$\begin{array}{rr}15 & 20 \\ 11 & \mathrm{n} / \mathrm{a} \\ 3 & 14 \\ 0 & 5 \\ 0 & 0 \\ 1 & 1\end{array}$


TABLE Va

RESULTS IN 12 CASES SUBJeCted tO BILATERAL OPERATION 1 FOLLOWED UP 2 YeARS OR MORE

Twelve Cases

Grand Mal

Minor Major

Temperamental Disturbance

Present before operation

Attacks absent post-operatively (previously present)

Improved

Unchanged

Worse

8
4
1
2
2

TABLE Vb

RESULTS IN FOUR CASES SUBJECTED TO BILATERAL OPERATION 1 FOLLOWED UP FOR AT LEAST 2 YEARS BEFORE OTHER PROCEDURES

Four Cases

Grand Mal

Psychomotor

Temperamental Disturbance

Minor Major

Present before operation

Attacks absent post-operatively (previously present)

Improved

Unchanged

Worse

$\begin{array}{lll}2 & 3 & 4 \\ 0 & 3 & 0 \\ 1 & 0 & 3 \\ 1 & 0 & 1 \\ 0 & 0 & \end{array}$

TABLE Vc

RESULTS IN SIX CASES SUBJECTED TO UNILATERAL OPERATION 1 FOLLOWED UP FOR 2 YEARS OR MORE

\begin{tabular}{|c|c|c|c|c|}
\hline \multirow[t]{2}{*}{ Six Cases } & \multirow[t]{2}{*}{ Grand Mal } & \multicolumn{2}{|c|}{ Psychomotor } & \multirow{2}{*}{$\begin{array}{l}\text { Temperamen } \\
\text { Disturbance }\end{array}$} \\
\hline & & Minor & Major & \\
\hline Present before operation & 5 & 4 & 2 & 3 \\
\hline Attacks absent post-operatively (previously present) & 1 & 1 & 2 & - \\
\hline Improved & 2 & 1 & 0 & 3 \\
\hline Unchanged & 2 & 1 & $\mathbf{0}$ & 0 \\
\hline Worse & 0 & 1 & 0 & 0 \\
\hline
\end{tabular}

TABLE VI

SUMMARY OF RESULTS OF UNILATERAL OPERATION IN 10 NON-PSYCHOTIC CASES

Grand Mal

Present before operation

Attacks absent post-operatively (previously present)

Improved

Unchanged

Worse
Not yet known

Msychomotor

Temperamental Disturbance

$\begin{array}{ll}4 & 6 \\ 3 & -5 \\ 0 & 0 \\ 0 & 0 \\ 0 & 1\end{array}$

TABLE VII

SUMMARY OF RESULTS OF BILATERAL OPERATIONS IN SIX PSYCHOTIC PATIENTS

Grand Mal

\begin{tabular}{ll} 
Psychomotor \\
\hline Minor Major
\end{tabular}

Aggressiveness

Psychosis

6
5
0
1

Present before operation
Attacks absent post-operatively (previously present)

Improved

Unchanged

Worse

Not yet known

4

2
1
0
1
0
0

$\frac{6}{0}$


TABLE VIII

SUMMARY OF RESULTS IN ALL 31 NON-PSYCHOTIC CASES

Grand Mal

\begin{tabular}{ll} 
Psychomotor & $\begin{array}{l}\text { Temperamental } \\
\text { Disturbance }\end{array}$ \\
\hline Minor $\quad$ Major &
\end{tabular}

Present before operation

Attacks absent post-operatively (previously present)

Improved

Unchanged

Worse

Not yet known

Minor

27
8
11
3
1
4

TABLE IX

SUMMARY OF RESULTS IN ALL 38 CASES, PSYCHOTIC AND NON-PSYCHOTIC, BILATERAL AND UNILATERAL

\begin{tabular}{|c|c|c|c|c|}
\hline \multirow[t]{2}{*}{ Grand Mal } & \multicolumn{2}{|c|}{ Psychomotor } & \multirow{2}{*}{$\begin{array}{l}\text { Temperamental } \\
\text { Disturbance }\end{array}$} & \multirow[t]{2}{*}{ Psychosis } \\
\hline & Minor & Major & & \\
\hline 32 & 24 & 21 & 32 & 7 \\
\hline 9 & 8 & 15 & $\overline{20}$ & - \\
\hline 13 & 5 & 3 & 23 & 0 \\
\hline 5 & 6 & 1 & 7 & 7 \\
\hline 1 & 6 & 0 & 0 & 0 \\
\hline 4 & 3 & 2 & 2 & 0 \\
\hline
\end{tabular}

Present before operation

Attacks absent post-operatively (previously present)

Improved

Unchanged

Worse

Not yet known

$\begin{array}{rrr}20 & 19 & 26 \\ 6 & 14 & -19 \\ 4 & 3 & 5 \\ 5 & 0 & 0 \\ 6 & 0 & 2\end{array}$

disturbance of recent memory, lasting about a week. $\mathrm{He}$ had previously been subnormal in intelligence, but the memory deficit was readily recognizable as an addition to his previous state. After a week it cleared completely. No formal psychometric tests are available for this operation as no facilities were available at the time, but the memory defect described by Scoville and Milner (1957) is so characteristic that it is quickly appreciated by anyone looking for it, and indeed is usually complained of by the patient. Apart from the case cited above it did not occur at any time.

No case had signs of damage to the optic tract, but where examination was possible restriction of the upper medial sector in the opposite homonymous field was usually present to a less degree than is found in a $5 \mathrm{~cm}$. lobectomy. The lobotomy cut tends to be $4.5 \mathrm{~cm}$. behind the anterior end of the lateral projection of the Sylvian fissure and the visual defect is consistent with cutting the most rostral fibres of the loop in the optic radiation. The visual fields were examined in detail in eight cases. Professor Brodie Hughes kindly supplied this report:

'In two cases the fields were normal (nos. 7 and 14). In five there were slight changes in the upper homonymous sector adjacent to the vertical meridian. These were quite slight and in all cases less than those described by Falconer but they were of the same character, namely a depression in this sector, quite narrow and closely adjacent to the vertical meridian. It is interesting that though two of these cases had a bilateral operation field defects appeared on only one side. The last case (no. 8) also had slight depression in the upper homonymous quadrant but this was of rather different character from the others. It was very slight indeed but much more widespread and probably affected the whole of the upper quadrant without any paravertical predilection as in the usual cases.'

PATHOLOGICAL ANATOMY Fortunately no patient died who had had a lobotomy, but one subsequently required a unilateral temporal lobectomy because of persistent attacks (case 30). In this polar $5 \mathrm{~cm}$. there was no evidence of specific focal degeneration in the cortex of the resected material, no marginal gliosis, nor glial increase in the white matter but of course this is to be expected, and reflects the multisynaptic nature of the pathways concerned.

One patient treated in the past by temporal lobectomy committed suicide 15 months later, and examination of this brain revealed degeneration of many fibres passing through the temporal isthmus, indicating that a high proportion of these originated in those anterior polar parts of the temporal lobe which are removed in the treatment of unilateral temporal lobe epilepsy in standard practice. The anatomical findings were very similar in detail to those reported by van Buren and Yakoulev (1959) in their study of a brain from a case of anterior temporal resection, except that there was in the present case an unexplained patch of gliosis passing up the posterior margin of the globus pallidus in the operated hemi- 
sphere and apparently crossing through the corpus callosum to reappear in a similar position in the unoperated hemisphere.

The results support the following conclusions:-

1 All the operations can be performed unilaterally or bilaterally without producing any demonstrable or subjective intellectual deficit.

2 Operation no. 1 through the temporal isthmus is indicated for major psychomotor attacks. Where these are accompanied by bouts of rage, fear, or aggressiveness, both the fits and the temperamental disturbance are likely to be benefited; in over $90 \%$ of non-psychotic bilateral cases in respect of the major psychomotor epilepsy (Table IV) and in all cases in respect of aggressiveness in non-psychotic bilateral cases (see Table II).

3 Where grand-mal attacks accompany psychomotor epilepsy, their frequency may be greatly reduced by operation no. 1 , and may even be abolished (Table V).

4 Unilateral operations are less successful than bilateral. It was noticed that unilateral cases were more likely to have prominent focal abnormality in the lateral temporal regions.

5 It is too early to assess the results from hippocampal sections directed at minor psychomotor attacks, but no intellectual deficit follows the operation and early results give the impression at present that the combination of operations nos. 1 and 2 is rather more effective in reducing all forms of epilepsy in these cases than operation no. 1 alone.

6 After basal frontal lobotomy the only consistent improvement seen is in psychiatric symptoms of depression, tension, and hypochondria (Table IIa). Epileptic attacks may be better or may be worse. Paranoid features are consistently worse.

\section{DISCUSSION}

The approach to the treatment of epilepsy by cutting tracts without removing tissue must depend first on the principle that a part of the brain influences the behaviour of an individual either by effector pathways influencing the soma and the environment or by connexions influencing the function of the rest of the brain. Focal hypersynchrony due to localized disease can affect thresholds of activity in other parts of the brain and also may spread at intervals to produce a clinical seizure. The second principle of the treatment is that both forms of propagation traverse neural pathways, of which the most important potential ones are those connecting a diseased part with diffuse projection systems in the diencephalon. This principle differs from the early conceptions of a spread in the cortex itself as in Jacksonian epilepsy, though whether subcortical structures would nowadays be left out of consideration even $\bar{z}$ in this connexion is perhaps doubtful. Only if neural pathways are relevant, discrete, constant, and unique yet dispensable, will treatment by lobotomy be successful. The temporal isthmus merits serious consideration as possibly fulfilling all the criteria required. The alveus and the fimbria may form a similar structure in regard to the hippocampus. Whether the anterior parts of the temporal lobe can still perform any function at all when thus deprived of certain connexions must also be con- $\stackrel{0}{+}$ sidered. If not, then lobotomy would be equivalent to lobectomy. The ordinary cortico-cortical connexions by white matter are still present, however, and their role in the absence of other connexions is not clear.

Only the results of attempts at lobotomy will furnish any answer to these questions. The findings in this study indicate that spread of the epileptic process is reduced or even abolished by selective section of the deeper pathways. Further, these procedures produce no intellectual or memory deficit, nor serious character changes, suggesting $\sim$ that the other connexions that have not been curo allow the cortical structures to perform some usefi function still. This argument is not conclusive, as the equivalent bilateral rostral temporal lobectom may not necessarily mutilate intellectual functionwe do not know - but the frightful consequences of bilateral lobectomy that have now been reported o\& several occasions mean that great care must be taken before accepting such a view. Since temper $\vec{\varphi}$ mental disturbances in the form of attacks of un- $\omega$ controllable rage and violence are virtually abolished by lobotomy through the temporal isthmus the implication is that under certain circumstances spread of the epileptic process by this pathway carries a certain positive function of emotional significance. Minor attacks of psychomotor type may be treatable by section of the hippocampus just behind the uncus if the appropriate focus lies in the amygdaloid nucleus or uncus. Minor attacks may theoretically still occur by spread through the hippocampus caudal to this plane but it would seem to be impracticable to operate at a more posterior? level because of potential risk to recall and memory. $\frac{3}{3}$ 'Frontal overpreponderance' after such operations may be mitigated by a very conservative basal frontal lobotomy. The orbital surface of the frontal lobe may be the site of the epileptogenic process but $\frac{}{5}$ E.E.G. abnormalities in this area tend to diminish with age so that such frontal operations should be approached with great caution in younger subjects. N

Paranoic mental states are not improved by these lobotomies. Other neural circuits must be considered in such states, and the results of animal 
experiments commend the cingulate region, especially the posterior cingulate gyri, for consideration. Investigation is therefore being directed towards this region. With removal of important 'feedback' connexions it is natural that others should appear overpreponderant, and descending influences from the cingulate region merit further investigation.

In cases of strictly unilateral temporal lobe epilepsy which, if intractable clinically, are prone to show abnormalities in the E.E.G. over the lateral surface of the temporal lobe, unilateral partial lobectomy may ultimately be necessary to achieve abolition of seizures, but lobotomy is warranted in the first instance, especially if such abnormality on the lateral surface of the temporal lobe is inconspicuous.

\section{SUMMARY}

The possibility of relieving psychomotor epilepsy by cutting nerve fibre tracts in the temporal lobes has been investigated. Since 195638 cases of psychomotor or mixed epilepsy have been treated by unilateral or bilateral temporal focal lobotomy.

It was found that lobotomy of the temporal lobe isthmus in the roof of the descending horn greatly improved major psychomotor attacks and the temperamental disturbances of uncontrollable rage or fear, and improved grand mal to some extent.

Basal frontal lobotomy improved depression and hypochondria but did not consistently improve the ictal manifestations.

Hippocampal section behind the uncus was used in conjunction with lobotomy of the isthmus in an attempt to improve minor attacks of confusion and automatism but too recently for proper assessment.

No deficit of intellect or memory was found after any of these procedures. None of them improved paranoid features.

Psychomotor epilepsy with unilateral focal discharges and with abnormalities on the lateral aspect of the lobe sometimes still requires the standard method of partial lobectomy.

I am grateful to Professor Brodie Hughes, Dr. Turner McLardy, and Mr. Peter Clark for their help and criticism during preparation of the report, to Dr. R. W. Tibbetts for his continued support and encouragement, to numerous colleagues for referring the cases, and to Miss Audrey Phillips for her help and advice throughout the years with the E.E.G. recordings.

\section{REFERENCES}

Bailey, P., Green, J. R., Amador, L., and Gibbs, F. A. (1953). Res. Publ. Ass. nerv. ment. Dis., 31, 341.

Buren, J. M. van, and Yakoulev, P. I. (1959). Acta anat. Basel, 39, 1.

Dax, E. C., and Radley-Smith, E. J. (1948). Brit. J. Surg., 36, 74. Freudenberg, R. K., Reitman, F., and Radley-Smith, E. J. (1948). Postgrad. med. J., 24, 415.

Falconer, M. A., Hill, D., Meyer, A., Mitchell, W., and Pond, D. A. (1955). Lancet, 1, 827.

Foerster, O., and Penfield, W. (1930). Brain, 53, 99.

Klüver, H., and Bucy, P. C. (1939). Acta Neurol. Psychiat., 42, 979.

McGregor, J. S., and Crumbie, J. R. (1941). Lancet, 2, 7.

Penfield, W., and Flanigin, H. (1950). Arch. Neurol. Psychiat. (Chicago), 64, 491 .

the Human Brain. Little, Brown, Boston.

- and Paine, K. (1955). Canad. med. Ass. J., 73, 515.

Reitman, F. (1946). Amer. J. Psychiat., 103, 238.

Russell, W. R., and Espir, M. L. E. (1961). Traumatic Aphasia. Oxford University Press, London.

Scoville, W. B., and Milner, B. (1957). J. Neurol. Neurosurg. Psychiat., $20,11$.

Turner, E. A. (1954). Brain, 77, 448

Turner, E. (1955). Lancet, 2, 1305. 